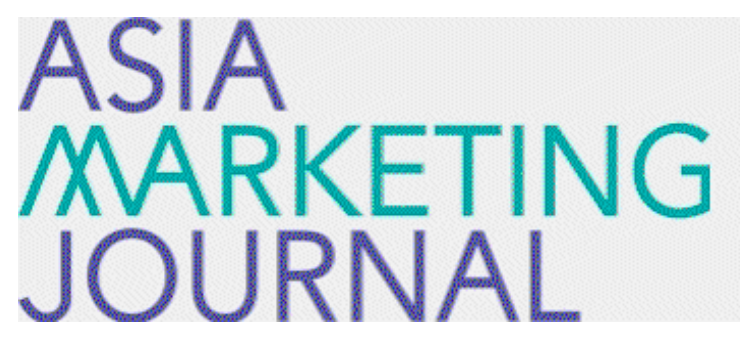

ASIA MARKETING JOURNAL

Volume 13 | Issue 3

Article 4

$10-30-2011$

\title{
공동마케팅제휴에 있어 상호의존성과 갈등의 관계에 대한 연구
}

Ho Taek Yi

Young Wook Cho

Ju Young Kim

Follow this and additional works at: https://amj.kma.re.kr/journal

Part of the Marketing Commons

\section{Recommended Citation}

Yi, Ho Taek; Cho, Young Wook; and Kim, Ju Young (2011) "공동마케팅제휴에 있어 상호의존성과 갈등의 관 계에 대한 연 구," Asia Marketing Journal: Vol. 13 : Iss. 3 , Article 4.

Available at: https://doi.org/10.53728/2765-6500.1288

This Article is brought to you for free and open access by Asia Marketing Journal. It has been accepted for inclusion in Asia Marketing Journal by an authorized editor of Asia Marketing Journal. 


\title{
공동마케팅제휴에 있어 상호의존성과 \\ 갈등의 관계에 대한 연구
}

\section{An Empirical Investigation of Relationship Between Interdependence and Conflict in Co-marketing Alliance}

\author{
이 호 택(Yi, Ho Taek)* \\ 조 영 욱(Cho, Young Wook)** \\ 김 주 영 $(\mathrm{Kim}, \mathrm{Ju} \text { Young })^{* * * *}$
}

본 연구는 지금까지 유통분야에서 제조업자와 판매업자간에 관계를 연구해오던 상호의존성의 개념 을 판매업자간의 공동마케팅 제휴관계에 적용하였다. 제휴관계에 있는 양자 간의 의존성과 상호의존 성이 갈등에 미치는 영향을 사회학 분야에서 상호의존성과 갈등 간의 관계에 대해 상반된 견해를 제 시하는 이론인 갈등 나선형 이론과 쌍무적 억제이론으로 설명해보고자 하였다. 기존의 연구들이 설문 을 통해 변수간의 관계를 파악하였다면, 본 연구에서는 이동통신사와 공동마케팅 제휴관계에 있는 181 개 기업의 거래데이터 및 설문을 동시에 이용하였으며 상호의존성의 선행요인으로 거래기간, 거래 빈도, 거래선의 수, 거래특유자산 등의 변수를 도출하여 상호의존성과의 관계를 파악하였다.

실증분석결과, 이통통신사의 제휴서비스 환경에서는 상호의존성의 총합이 증가할수록 갈등수준 역 시 증가함을 알 수 있었으며 따라서, 상호의존성과 갈등간의 관계를 설명하기 위해서는 쌍무적 억제 이론 보다는 갈등 나선형 이론이 더 적합함을 알 수 있었다. 아울러, 이동통신사의 관점에서는 거래 기간, 거래빈도, 거래특유자산이, 제휴파트너 관점에서는 거래빈도, 거래특유자산, 거래선의 수가 각각 상대방에 대한 의존성에 영향을 미치는 요소로 도출되었다. 이를 통해 이통통신사 및 제휴파트너 관 점에서 효율적인 갈등관리 전략을 제시하였으며 학문적 시사점들과 연구의 한계점에 대해 제시하였다.

핵심개념: 갈등, 갈등 나선형이론, 공동마케팅 제휴, 상호의존성(상호의존성 불균형, 상호 의존성 합), 쌍무적 억제이론, 이동통신

서강대학교 경영전문대학원 박사과정(hotaekyi@sogang.ac.kr), 주저자

** 서강대학교 경영전문대학원 석사(ywcho@sogang.ac.kr), 교신저자

*** 서강대학교 경영전문대학원 교수(jkimsg@sogang.ac.kr) 


\section{I. 서 론}

경영환경의 불확실성과 시장의 성숙은 기업 간의 경쟁심화를 가속화 시키고 있으며, 지속 적인 성장과 경쟁우위를 확보하기 위한 기업 차원의 다양한 방법들이 시도되고 있다. 그러 나, 기업은 가용할 수 있는 자원이 한정되어 있고, 따라서 모든 영역에서 경쟁우위 요소를 확보한다는 것은 현실적으로 불가능하기 때문에, 다른 기업들과의 의존적인 관계를 형성함으로 써 부족한 부분을 보강하고 있다(Pfeffer and Salancik 1978). 이러한 의존관계는 기업 간 사업 제휴(business alliances)나 자발적인 협력협정 (voluntary collaborative arrangements) 등의 형 태로 나타나고 있으며 제품, 서비스, 지식 등을 공유함으로써 상호발전을 도모하는 시도는 지속 적으로 증가하고 있다(Kandemir et al. 2006).

이와 같은 추세를 반영하듯, 최근 상품/브랜 드 제휴, 가격제휴, 채널제휴, 프로모션 제휴 등 기업 간 공동마케팅 제휴(co-marketing alliances) 는 증가하고 있는데, 미국에서는 마케팅 제휴를 통한 매출이 연간 $25 \%$ 이상씩 성장하고 있다 (Rich 2003). 이러한 공동마케팅 제휴의 추세가 증가함에도 불구하고 $40 \sim 70 \%$ 의 제휴는 불만 족스러운 성과를 낳고 있으며(Lorange and Roos 1992), 60\%는 실패로 끝나는 등(Porter and Fuller 1986; Spekman et al. 2000) 제휴 당사자 들 간의 이해관계의 상충 또는 갈등으로 인해 제 휴가 결렬(Yi et al. 2010)되는 사례를 찾아볼 수 있다.

일찍이 사회학과 정치학에서는 갈등에 대한 연 구가 많이 진행되어 왔는데, Pruitt와 Rubin(1986)
은 갈등의 확대에 있어 공격자-방어자 모델, 갈 등 나선형이론, 구조적 변화모델을 제안하였고, Lawler(1986)은 쌍무적 억제이론과 갈등 나선형 이론을 제시하여 갈등관리(conflict management) 매커니즘을 설명하기도 하였다. 또한 McCarthy (2010)는 최근연구에서 커뮤니케이션 프로세스 상의 갈등분석을 위해 갈등 나선형 이론과 힘의존이론을 제시하였다. 마케팅 분야에서는 쌍 무적 억제이론, 갈등 나선형 이론, 힘-의존이론 등이 갈등관리에 대한 연구에 사용되어 왔는데, 특히 힘과 의존성이 갈등에 영향을 미치는 중 요한 변수로 연구되어 왔다.

마케팅 분야에서는 Gundlach와 Cadotte(1994) 에 의해 상호의존성에 대한 연구가 본격적으로 시작되었다. 이후 Kumar et al.(1995)는 상호의 존성의 하위 개념(상호의존성의 총합과 불균형) 을 측정하고 갈등과 신뢰 그리고 몰입 등에 미치 는 영향을 규명하였다. 그 이후 의존성과 갈등 의 관계에 있어 연구들이 진행되어 왔지만, 그 복잡성에 대해 충분한 규명이 이루어지지 않았 기 때문에 의존성과 갈등에 대해서 상반된 두 가 지 견해가 존재 해왔다(Frazier 1999). Frazier (1999)는 의존성이 갈등을 감소시키고 관계강 화 및 결속을 유지시킨다고 하였지만, 반대로 의존성이 갈등을 증가시키고 강압적인 통제를 유발한다고 주장하는 견해(Brown et al. 1983; Frazier et al. 1989)도 있다.

어찌 보면, 상반된 두 가지 이론 및 결과가 있는 원인에는 의존성과 갈등에 대한 연구들의 대부분이 의존성을 양자 간 거래에서의 상호의 존성의 개념이 아닌 한쪽 측면에서의 의존성을 측정하였기 때문일 수도 있다. Kumar et al. (1995)의 연구에서도 쌍무적 억제이론에 근거 
하여 상호의존성과 갈등간의 관계를 설명하였 지만, 상호의존성의 경우 양방향을 측정한 반면 갈등에 대해서는 일방향 만을 측정한 결과를 제시하였다. 국내연구로는 쌍무적 억제이론과 갈등나선형이론을 활용하여 상호의존성과 갈등 간의 관계에 대해 분석한 김종근과 김재욱의 연구(2005)가 있으나, 이 연구 역시 갈등에 대 한 측정에 있어서 한계점을 보이고 있다.

본 연구에서는 공동마케팅 제휴를 상호 의존 적인 관계(Anderson and Narus 1990)로 정의하 고, 제휴 양자 간의 의존성과 상호의존성이 갈 등에 미치는 영향을 갈등나선형 이론과 쌍무적 억제이론을 바탕으로 파악하고자 한다. 기존의 연구들이 설문을 통해 이러한 변수간 관계를 파악하였다면, 본 연구에서는 실제 데이터와 설 문을 동시에 이용해서 변수간 관계를 분석하였 다. 아울러 기존 연구들은 제조업자와 공급업자의 관계와 같은 수직적 관계(vertical relationship) 에서의 의존성과 갈등간의 관계를 다루었다면, 본 연구에서는 국내 이동통신사 고객로열티 서비스 제휴와 같은 수평적 관계(horizontal relationship)에서 통신사와 제휴파트너사 양방 향 측정을 통해 상호의존성과 갈등의 관계에 대해 규명하고자 한다.

\section{II. 이론적 배경}

\section{1 공동마케팅 제휴에 관한 연구}

‘공동마케팅 제휴'란, 기업들이 개별적으로 제 공하는 편익에 대해 소비자 인지도를 향상시키
기 위해 수평적 관계에 있는 기업들 사이의 공 생마케팅의 일종(Bucklin and Sengupta 1993) 으로, 공동마케팅 제휴를 통해 기업은 고객충성 도를 유지하거나 신규 구매 수요를 유발시킬 수 있으며(이석규, 김경식 2005) 제휴할인과 같 은 공동마케팅 제휴 프로그램을 통해 소비자의 구매를 촉진하거나 객단가를 증가시킬 수도 있 다(신영식, 차경천 2011). 공동마케팅 제휴의 예는 우리주변에서 흔히 살펴볼 수 있는데, 스 타벅스와 SK Marketing \& Company 사이의 기프티콘 제휴, $\mathrm{LG}$ 전자와 프라다의 제휴를 통 한 프라다폰, 남양유업과 OK Cashbag의 제휴 등 다수의 상품과 서비스에서의 제휴 성공 사 례를 찾아 볼 수 있다.

그러나 공동마케팅 제휴는 해당 제품 또는 서 비스에 부정적인 영향을 미치기도 하는데, 자사 의 제품과 파트너사의 제품의 적합도가 떨어지 면, 소비자에게 정체성을 명확하게 전달하지 못 하고(Park et al. 1996; Venkatesh and Mahajan 1997), 맥락효과로 인해 파트너 기업의 미끼 브랜드로 전락할 수도 있다(Rathneshwar and Shocker 1991). 또한 제휴관계에서 파트너의 희 생을 통해 시장입지를 강화하거나, 상대방의 전 문적 기술 등을 무상으로 확보하려는 제휴파트 너의 기회주의적 행동이 유발될 가능성도 있다 (김영, 배일현 2006). 실제로 많은 공동마케팅 제휴 상황에서 갈등이 발생하고 있고 이러한 제휴의 상당수가 제휴실패로 연결되고 있으며 (Gates 1993), 이러한 제휴사례 중에 대략 $70 \%$ 가 실패로 끝난다(Parkhe 1993).

국내사례로, 2004년 SKT는 할인율 부담과 관 련하여 제휴 외식업체의 반발로 CJ푸드빌, 베 니건스 등과의 제휴를 중단하였고, 2005년에는 
〈표 1〉 공동마케팅 제휴에 관한 연구

\begin{tabular}{|c|c|c|c|c|}
\hline 연구구제 & 논문 & 저자 & 변수 & Study Field \\
\hline \multirow{4}{*}{$\begin{array}{l}\text { Alliance } \\
\text { Success }\end{array}$} & $\begin{array}{l}\text { Organizing Successful } \\
\text { Co-marketing Alliances }\end{array}$ & $\begin{array}{l}\text { Bucklin and Sengupta, } \\
\text { Journal of Marketing,1993 }\end{array}$ & $\begin{array}{l}\text { - project management/prject payoff } \\
\text { - partner match/age of alliance } \\
\text { - rate of technological change }\end{array}$ & 컴퓨터/반도체 산업 \\
\hline & $\begin{array}{l}\text { A Model of Distributor Firm } \\
\text { and Manufacturer Firm } \\
\text { Working Partnerships }\end{array}$ & $\begin{array}{l}\text { Anderson and Narus, } \\
\text { Journal of Marketing, } 1990\end{array}$ & $\begin{array}{l}\text { - influence by partner firm } \\
\text { - relative dependence/communication } \\
\text { - conflict/trust/cooperation } \\
\text { - outcome given comparison level }\end{array}$ & $\begin{array}{l}\text { 제조업자·유통업자 } \\
\text { (110여개 산업군) }\end{array}$ \\
\hline & $\begin{array}{l}\text { Long-term Manufacturer-Supplier } \\
\text { Relationships: Do They Pay Off for } \\
\text { Supplier Firms? }\end{array}$ & $\begin{array}{l}\text { Kalwani and Narayandas, } \\
\text { Journal of Marketing, } 1995\end{array}$ & $\begin{array}{l}\text { - the level of sales } \\
\text { - inventory holding and control costs } \\
\text { - selling price/profitability }\end{array}$ & $\begin{array}{l}\text { 제조업자· 공급업자 } \\
\text { (컴퓨터, 기계장치 등) }\end{array}$ \\
\hline & $\begin{array}{l}\text { Alliance Orientation: } \\
\text { Conceptualization, Measurement, } \\
\text { and Impact on Market Performance }\end{array}$ & $\begin{array}{l}\text { Kandemir, et al, } \\
\text { Journal of the Academy of } \\
\text { Marketing Science, } 2006\end{array}$ & $\begin{array}{l}\text { - scanning/coordination } \\
\text { - learning/alliance network performance } \\
\text { - market performance/market turbulence } \\
\text { - technology/turbulence }\end{array}$ & $\begin{array}{l}\text { 화학, 기계, 전자장비, } \\
\text { 컴퓨터, 데이터프로세싱, } \\
\text { 엔지니어링 등 }\end{array}$ \\
\hline \multirow{3}{*}{$\begin{array}{l}\text { Alliance } \\
\text { Failure }\end{array}$} & $\begin{array}{l}\text { Learning and Protection of } \\
\text { Proprietary Assets in Strategic } \\
\text { Alliance: Building Relational Capital }\end{array}$ & $\begin{array}{l}\text { Kale, Singh, and Perlm utter, } \\
\text { Strategic Management Journal, } 2000\end{array}$ & $\begin{array}{l}\text { - relational capital/conflict management } \\
\text { - partner fit/previous alliances } \\
\text { - alliance duration/partner nationality } \\
\text { - alliance governance }\end{array}$ & $\begin{array}{l}\text { 제약, 화학, 컴퓨터, } \\
\text { 전자, 통신 산업 }\end{array}$ \\
\hline & $\begin{array}{l}\text { Survival of Businesses Using } \\
\text { Collaborative Relationships to } \\
\text { Commercialize Complex Goods }\end{array}$ & $\begin{array}{l}\text { Mitchell and Singh, } \\
\text { Strategic Management Journal, } 1996\end{array}$ & $\begin{array}{l}\text { - collaboration/number of relationships } \\
\text { - sudden change/prior performance }\end{array}$ & $\begin{array}{l}\text { 컴퓨터 하드웨어 및 } \\
\text { 소프트웨어 산업 }\end{array}$ \\
\hline & $\begin{array}{l}\text { An Empirical Investigation of } \\
\text { Relational Conflicts in } \\
\text { Co-Marketing Alliances }\end{array}$ & $\begin{array}{l}\text { Yi,Lee, and Dubinsky, } \\
\text { Journal of B2B Marketing, } 2010\end{array}$ & $\begin{array}{l}\text { - environmental uncertainty } \\
\text { - alliance specific assets } \\
\text { - replaceability/compensation }\end{array}$ & 신용카드사 \\
\hline
\end{tabular}

분담금 조정에 실패하여 스타벅스, 아웃백스테 이크 등과 결별하였다. 온라인 서점 YES 24는 2010년 4월 LGT와의 제휴서비스인 'OZ\&조이 북'에 따른 손실누적의 배상과 관련하여 LGT 를 대상으로 손해배상소송 및 불공정거래 제소 를 하는 등 제휴종료나 결렬의 사례를 쉽게 찾 아 볼 수 있다. 이렇게 제휴가 결렬되는 경우는 증가하였지만, Yi et al. (2010)의 연구를 제외 하고 대부분의 연구들은 마케팅 제휴의 원인이 나 제휴 성공에 영향을 미치는 영향에 관한 것
이고, 실패 혹은 갈등의 근본적인 원인에 대한 연구는 아직 부족한 상황이다.

\section{2 갈등에 대한 연구}

과거 사회학과 정치학 분야에서 갈등에 관한 많은 연구가 진행되어 왔다. Pruitt and Rubin (1986)은 갈등을 관리하는 방법으로 공격자-방 어자모델, 갈등나선형 이론, 구조적 변화모형을 제시함으로써 다양한 관점에서 갈등에 대한 원 
인을 파악하고자 하였다. 또한 Lawler(1986)는 힘의 균형과 불균형 상황에서 대립되는 이론인 쌍무적 억제이론과 갈등 나선형이론을 제시하 였고, 이후 이 두 가지 이론들은 마케팅 채널에 서 힘과 의존성에 관련된 연구를 설명하는 근 간이 되어왔다(Kumar et al. 1995, 1998; 김재 욱 외 2004; 김종근, 김재욱 2005). McCarthy (2010)는 갈등을 분석하기 위한 이론으로 갈등 나선형 이론과 힘-의존이론을 제안하였다. 특히 Lawler와 Bacharach(1987)는 관계형성을 통해 발생하는 의존성과 힘의 강압적인 형태를 확인 함으로써 갈등에 관한 이론을 발전시켜 왔는데, 이들에 의하면 갈등나선형 이론과 힘-의존이론 중 어떠한 이론도 개별적으로는 갈등을 충분히 설명할 수 없다고 하였다. 본 연구에서는 마케 팅 영역에서 힘과 의존성에 관한 매커니즘을 설명하는데 근간이 되는 힘-의존이론과 쌍무적 억제이론 그리고 갈등나선형 이론에 대해 살펴 보고자 한다.

힘-의존이론(power-dependence theory)은 사 회적 관계에서 힘은 의존성에 근거하기 때문에 거래 일방의 힘은 상대방의 의존성에 기인한다 는 이론이다(Emerson 1962). 여기서 힘이라는 것은 거래나 제휴파트너의 의사결정을 통제하 거나 영향을 미칠 수 있는 능력으로 한 기업이 다른 기업의 신념, 태도, 행동에 영향을 줄 수 있는 잠재력이라고 할 수 있다(Anderson and Narus 1990). 따라서 힘이 존재하기 위해서는 둘 이상의 대상 즉, 힘을 행사하는 대상(power from) 과 당하는 대상(power to)이 동시에 공존 (co-active)하는 상태어야 한다(Coleman 2000). 양자 간의 관계 또는 제휴관계에서 제휴사 $\mathrm{A}$ 의 제휴파트너 $\mathrm{B}$ 에 대한 의존성은 다음의 두
가지 변수로 결정된다. 첫째가 $\mathrm{B}$ 가 통제하는 것에 대한 $\mathrm{A}$ 의 바램(desire)이 얼마나 강렬한 지에 대한 것이고 둘째가 $\mathrm{A}$ 가 $\mathrm{B}$ 를 제외한 다 른 거래업체 또는 제휴파트너로부터 필요한 것 을 얼마나 쉽게 획득할 수 있는 지에 관한 것 이다(Emerson 1962). 따라서 힘은 앞서 언급한 두 가지 측정변수로 결정되며, 이 두 가지 변수 들을 살펴봄으로써 관계의 균형을 평가할 수 있다.

쌍무적 억제이론(bilateral deterrence theory) 은 기존에 사회심리학 분야에서 연구되어 왔던 억제이론이 거래상에 있는 양쪽 방향의 관계가 아닌 한쪽 방향만을 고려했다는 점에서 출발하 여, Lawler에 의해 정립되었으며 마케팅에서는 Kumar et al. (1995)의 연구를 통해 활용되기 시작하였다. 이 이론에 따르면 개인이나 기업은 자신이 힘을 행사할 경우에, 발생할 수 있는 보 복에 대한 두려움(fear of retaliation)과 상대방 의 공격에 대한 예상(expectation of attack)을 하게 되는데(Lawler 1986; Lawler et al. 1988) 양자 간 힘의 수준이 균형적인 상태에서는 힘 의 총합이 커질수록, 상대방에 의한 보복의 두 려움은 커지고 상대방의 공격에 대한 예상은 줄어들어 상호간의 강압적인 행위의 빈도는 줄 어든다는 것(Lawler et al. 1988)이다. 하지만 힘의 수준이 불균형적인 상태에서는, 상대적 힘 의 열위에 있는 기업으로부터의 보복의 두려움 이 줄어들어 힘의 우위에 있는 기업은 그 힘을 행사하게 되고, 열위에 있는 기업은 반대로 힘 의 우위에 있는 거래선에 대한 공격예상이 늘 어남에 따라 방어적 차원에서 힘을 행사하게 된다. 따라서 힘의 불균형 상태에서는 상호간의 힘의 사용이 증가한다(Lawler et al. 1988). 
초기 갈등나선형 이론(conflict spiral theory) 에서는 상대방에 대한 힘의 행사 중 위협에 대 한 두 가지 연구가설을 제시하였다(Deutsch and Krauss 1962). 첫 번째 가설은 힘을 행사 할 수 있는 기회가 단순히 주어지기만 해도 힘 의 행사가 증가한다는 것이다. 즉, 갈등 나선형 이론에서는 힘에 대한 행사 유혹을 힘을 행사 하는 원인으로 제시하였는데, 힘의 행사 유혹은 상대방의 행위와 상관없이 힘을 행사하고자 하 는 성향이며, 이는 자신이 지닌 힘에 따라 다르 다고 제시하였다(Lawler 1986; Lawler et al. 1988). 두 번째 가설은 관계상에 있는 당사자들 중 특정 당사자가 힘을 행사할 경우, 상대방은 이에 반응함으로써 상대방에게 힘을 행사한다 는 것이다. 하지만 초기의 갈등 나선형 이론도 억제이론과 같이 거래관계에서 일 방향만을 고 려하는 한계를 지니고 있었다. 따라서 양자 간 의 관계를 파악하기 위해 이후 연구에서는 상 대방이 힘을 행사하고자 하는 유혹에 대한 지 각과 상대방의 공격에 대한 예상을 고려하였다 (Lawler 1986; Lawler et al. 1988). 즉, 쌍무적 억제이론에서의 보복에 대한 두려움이 힘의 행 사에 대한 유혹으로 대체된 것이 갈등 나선형 이론의 특징이다.

이러한 갈등나선형 이론에 따르면 양자 간의 힘이 균등한 상황에서 힘의 총합이 커짐에 따 라 상호간의 비우호적인 행위는 증가하게 된다. 거래관계에 있어 한쪽의 힘이 증가하게 되면 자신의 힘을 행사하고자 하는 유혹이 증가하고, 또 다른 거래 일방은 상대방이 증가된 힘에 의 해 비우호적 행위를 할 가능성이 높다고 예상 함으로써 상대방에 대해 비우호적 행위를 할 가능성이 증가한다는 것이다(Deutsch and Krauss
1962). 반대로 힘이 불균형한 상황에서 힘의 우 위에 있는 거래당사자는 자신이 힘을 행사하지 않더라도 상대방으로부터 순종을 이끌어 낼 수 있기 때문에 힘을 행사할 필요성을 느끼지 못 하며, 힘의 열위에 있는 거래당사자 또한 힘을 행사하여 얻을 수 있는 이득이 적음을 알기 때 문에 힘을 행사하고자 하는 유혹을 적게 느끼 게 되어 결과적으로 양쪽 다 힘을 행사하지 않 게 된다. 이와 같이 갈등 나선형이론에서 상대 방의 공격에 대한 예상의 정의는 쌍무적 억제 이론과 동일하다. 하지만 쌍무적 억제이론에서 상대방의 공격에 대한 예상이 자신의 힘에 의 존한다는 것과는 달리, 갈등 나선형이론에서는 상대방의 힘에 의존한다는 점에서 차이가 있다 (Lawler and Blegen 1988). 즉 쌍무적 억제이 론은 자신의 힘을 항상 사용하고 싶은데, 보복 이 클 것 같으면 이에 반응하는 것이라고 가정 하고 있으며, 갈등 나선형이론은 상대방의 힘에 따라서 그쪽에서 힘을 사용할 유혹이 커지는 것에 대하여 대응하는 것이라고 가정하는 것이다.

\section{III. 연구설계 및 연구방법}

\section{1 의존성과 상호의존성}

전통적인 채널연구에서 의존성은 다양한 형태 로 정의할 수 있는데, 주로 거래선이나 파트너 를 대체할 수 있는 정도를 말한다(Heide and John 1988). 따라서 제휴관계에 있어 의존성이 란 파트너를 대체할 수 있는 다른 거래선을 찾 을 수 있는 정도로 측정할 수 있다(Brown et 
al. 1983; Buchanan 1992; Frazier and Rody 1991; Heide 1994; Heide and John 1988; Phillips 1981).

의존성이 거래관계 상대방에 대한 자사의 태 도 혹은 능력이라고 한다면, 상호의존성이란 상 대방에 대한 자사의 의존성뿐만 아니라 자사에 대한 상대방의 의존성을 같이 고려한 개념이라 고 할 수 있다. 따라서 거래관계에 있어 상호의 존성은 (1)개별 기업의 의존성, (2)거래관계를 형성하고 있는 기업들의 상호의존성의 총합 그 리고 (3)기업 간 상호의존성의 불균형 정도를 포함하는 개념이라고 볼 수 있다(Kumar et al. 1995).

상호의존성의 총합(total interdependence)이 란 거래 또는 제휴관계에 있어 각각의 기업들 이 가지고 있는 의존성의 합을 말하고 상호의 존성의 불균형(interdependence asymmetry)이 란 파트너에 대한 의존성과 반대로 파트너의 자사에 대한 의존성 사이에서의 차이를 말한다 (Emerson 1962; Lawler and Bacharach 1987). 이러한 차이는 상대적 의존성(relative dependence) 또는 상대적인 힘(relative power)이라는 이름으 로도 불린다(Anderson and Narus 1990; Emerson 1962; Frazier and Rody 1991; Lawler and Bacharach 1987). 상호의존성의 균형(symmetric interdependence)은 기업과 해당 기업의 거래선 사이의 의존성이 동일한 수준인 상태를 말하는 데, 의존성은 상대방에 대한 힘의 원천과 같은 개념(Emerson 1962)이기 때문에, 상호의존성의 총합과 상호의존성의 불균형은 다른 말로 그 기업의 제휴파트너에 대한 힘의 총합과 힘의 비대칭성과 동일한 개념으로 볼 수 있다.

기업 간 거래의 지속성에 대한 연구들과 의존
성에 대한 연구를 바탕으로 McCann과 Ferry (1979)는 의존성에 영향을 미치는 거래관계 요 소로 (1)거래기간, (2)거래빈도, (3)마케팅 투 자비용, (4)거래선의 수, (5)거래특유자산, (6) 자원흐름 방향 등의 6 가지 요소를 제시하였다. 이 중 본 연구에서는 제휴관계에서 실질적으로 계량화하기 어렵고, 다른 변수와 상관관계가 높 거나 비슷한 개념일 수 있다고 판단되는 (3)마 케팅 투자비용과 (6) 자원흐름방향을 제외한 4 가지 요소를 각각의 제휴사에 대한 의존성과 궁극적으로 상호의존성(상호의존성의 총합과 상 호의존성의 불균형)에 영향을 미치는 선행요인 으로 고려하였다.

먼저 공동마케팅 제휴에 있어 첫째, 거래기간 은 계약시점으로부터 지속된 기간을 의미하고, 거래빈도는 거래건수를 의미한다. 일반적으로 거래기간이 증가하거나 거래건수가 증가하면 거래비용이 절감되고 운영의 효율성이 높아지 는데(Kalwani and Narayndas 1995), 이와 같은 점 때문에 거래빈도와 기간이 증가하면 신뢰와 지속거래에 대한 기대가 증가하고(Anderson and Weitz 1989) 거래파트너에 대한 의존성이 증가 하게 되어 궁극적으로 상호의존성의 총합은 증 가하며(McCann and Ferry 1979), 상호의존성 의 불균형은 감소하게 될 것을 예상할 수 있다.

둘째로, 거래선의 수는 현재 거래하고 있는 상대방 이외의 다른 제휴 관계를 맺고 있거나 또 다른 관계를 형성할 수 있는 잠재적인 제휴 파트너 수를 의미한다. 대체할 수 있는 거래선 의 수가 많은 경쟁적 시장에서는 거래당사자가 쉽게 거래를 종결하고 다른 거래파트너로 거래 선을 바꿀 수 있기 때문에(한상린 2003), 거래 선의 수가 늘어남에 따라 거래파트너에 대한 
의존성이 줄어들어, 상호의존성의 합은 줄어들 고, 상호의존성의 불균형은 증가할 것을 예상할 수 있다. 마지막으로 거래특유자산은 해당 거래 또는 제휴관계에서 부가가치를 창출하는데 영 향을 미칠 수 있는 지식이나 기술로 해당 거래 이외의 다른 거래에는 영향을 미치지 못하는 자산을 말한다. 때때로 거래특유자산은 거래나 제휴관계에서 신뢰성을 증가시켜 오히려 기회 주의를 억제할 수 있는 환경을 만들어 주기도 하는데, Heide와 John(1990)의 연구에서는 특 정거래에만 사용가능한 자원의 양이 증가할수 록, 양 자 간의 장기적인 거래관계가 성립된다 고 하였으며, 따라서 이러한 상황에서 상호의존 성의 합은 증가하고 불균형은 감소할 것을 예 상할 수 있다. 따라서 이와 같은 기존연구의 내 용을 바탕으로 아래와 같은 가설을 세울 수 있 었다.

$\mathrm{H} 1$ : 거래관련 변수들은 제휴사 $\mathrm{A}$ 의 제휴파 트너 $\mathrm{B}$ 에 대한 의존성에 영향을 미칠 것이다.

$\mathrm{H} \mathrm{la}$ : 거래기간이 증가하면 제휴사 $\mathrm{A}$ 의 제 휴파트너 $\mathrm{B}$ 에 대한 의존성은 증가할 것이다.

$\mathrm{H} 1 \mathrm{~b}$ : 거래빈도가 증가하면 제휴사 $\mathrm{A}$ 의 제 휴파트너 $\mathrm{B}$ 에 대한 의존성은 증가할 것이다.

$\mathrm{H1c}$ : 거래특유자산이 증가하면 제휴사 $\mathrm{A}$ 의 제휴파트너 $\mathrm{B}$ 에 대한 의존성은 증 가할 것이다.

$\mathrm{HId}$ : $\mathrm{A}$ 의 거래선의 수가 증가하면 제휴사 $\mathrm{A}$ 의 제휴파트너 $\mathrm{B}$ 에 대한 의존성은 감소할 것이다.
$\mathrm{H} 2$ : 거래관련 변수들은 제휴사 $\mathrm{B}$ 의 제휴파 트너 $\mathrm{A}$ 에 대한 의존성에 영향을 미칠 것 이다.

$\mathrm{H} 2 \mathrm{a}$ : 거래기간이 증가하면 제휴사 $\mathrm{B}$ 의 제 휴파트너 $\mathrm{A}$ 에 대한 의존성은 증가 할 것이다.

$\mathrm{H} 2 \mathrm{~b}$ : 거래빈도가 증가하면 제휴사 $\mathrm{B}$ 의 제 휴파트너 $\mathrm{A}$ 에 대한 의존성은 증가 할 것이다.

$\mathrm{H} 2 \mathrm{c}$ : 거래특유자산이 증가하면 제휴사 $\mathrm{B}$ 의 제휴파트너 $\mathrm{A}$ 에 대한 의존성은 증가할 것이다.

$\mathrm{H} 2 \mathrm{~d}: \mathrm{B}$ 의 거래선의 수가 증가하면 제휴사 $\mathrm{B}$ 의 제휴파트너 $\mathrm{A}$ 에 대한 의존성은 감소할 것이다.

\section{2 상호의존성이 갈등에 미치는 영향}

마케팅 분야에서는 Gundlach and Cadotte (1994)에 의해 거래 일방이 아닌 거래 양방인 상호의존성에 대한 연구가 시작되었는데, 이들 은 거래관계에서 거래당사자들의 상대방에 대 한 의존성을 측정함으로써, 각각의 기업들의 의 존성을 향합 총합(magnitude)과 각각의 기업들 의 의존성의 차이인 불균형(asymmetry)를 제 시하였다. 이러한 상호의존성(상호의존성의 총 합과 상호의존성의 불균형)이 갈등에 미치는 영향에 대해 쌍무적 억제이론과 갈등나선형 이 론은 상반된 견해를 보이고 있다.

쌍무적 억제이론에 따르면 거래관계에 있어 거래당사자(이하 $\mathrm{A}$ )의 힘이 증가하면, 다른 거 래당사자(이하 $\mathrm{B}$ )는 $\mathrm{A}$ 를 공격할 경우 당할 보 복에 대한 두려움이 증가되어, $\mathrm{A}$ 에 대한 공격 
을 자제하게 되고, 이와 반대로 $\mathrm{A}$ 는 힘이 증가 하게 됨에 따라 $\mathrm{B}$ 가 공격할 가능성이 낮다고 예상하여 공격에 대한 필요성을 느끼지 못하게 된다(Bacharach and Lawler 1981; Lawler 1986; Lawler et al. 1988). 이와 반대로 거래당 사자간의 힘의 불균형이 증가하게 되어, $\mathrm{A}$ 가 힘의 우위를 확보하고 $\mathrm{B}$ 가 열위에 놓이게 되었 다고 가정할 때, $\mathrm{A}$ 는 힘의 우위에 있기 때문에 상대방에 대한 보복의 두려움이 감소함으로써 공격을 억제할 필요성을 느끼지 못하게 된다. 반면에 $\mathrm{B}$ 는 힘의 열위에 있기 때문에 상대방에 의한 보복의 위험성이 높지만 상대방이 공격할 가능성 또한 높다고 판단하기 때문에 $\mathrm{A}$ 가 공 격할 경우, 보복행위를 할 수 있음을 보여주기 위한 방편으로서의 비 우호적인 행위를 할 가 능성이 높아지게 된다.

이와 반대로 갈등 나선형 이론에 따르면, 힘 이 균등한 상황에서 힘의 총합이 커짐에 따라
자신의 힘을 행사하고자 하는 유혹이 증가되어 상호간 비우호적인 행위가 발생할 가능성이 증 가한다. 또한 힘의 불균형을 이루게 되면 우위 에 있는 당사자는 상대방이 순종(compliance) 할 것이라고 생각하기 때문에 힘을 행사하지 않고, 힘의 열위에 있는 당사자 또한 힘의 행사로 인 해 얻는 이득이 적을 것으로 판단하기 때문에 힘의 행사에 대한 유혹을 적게 느끼게 된다.

공동마케팅을 하는 현재의 연구상황에서 보 면, 통신사와 제휴사의 관계는 거의 대부분 제 휴사의 규모가 통신사보다 적고, 보유하고 있 는 정보의 양도 통신사가 더 많은 경우가 많 다. 따라서 힘의 불균형의 차이가 크다면, 이를 활용하여 갈등을 유발하기보다 현재의 관계를 유지하고자 할 것이며, 힘이 비슷하고, 상호의 존성이 큰 경우라면(즉, 규모가 비슷하다면), 힘을 행사하고자 하는 유혹이 커짐으로 제휴사 간 갈등이 증가될 될 것이라고 생각할 수 있다

\section{〈그림 1〉 연구모형'1)}

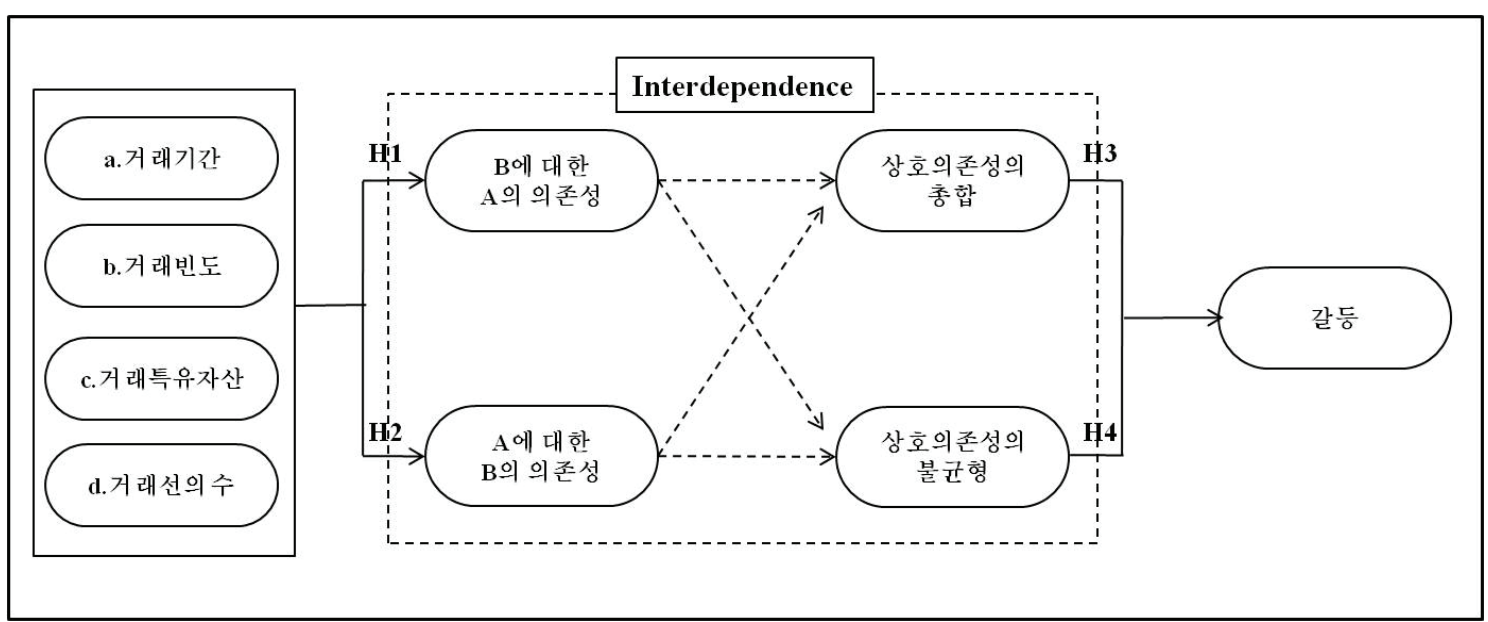

1) 상호의존성의 총합 $=(\mathrm{B}$ 의 $\mathrm{A}$ 에 대한 의존성 $+\mathrm{A}$ 의 $\mathrm{B}$ 에 대한 의존성 $)$

상호의존성의 불균형 $=\mid \mathrm{B}$ 의 $\mathrm{A}$ 에 대한 의존성 - $\mathrm{A}$ 의 $\mathrm{B}$ 에 대한 의존성 $\mid$ 
(Lawler, 1986; Lawler et al. 1988). 따라서 본 연구의 가설은 갈등나선형이론이 현재의 산업 에 더 맞을 것으로 판단되어 아래와 같이 설정 하였다.

$\mathrm{H} 3$ : (갈등나선형이론) 상호의존성의 총합이 증가할수록 갈등은 증가할 것이다.

$\mathrm{H} 4$ : (갈등나선형이론) 상호의존성의 불균형 이 증가할수록 갈등은 감소할 것이다.

\section{3 연구의 대상 및 자료수집방법}

본 연구는 공동마케팅 제휴에 있어 상호의존 성이 갈등에 미치는 영향과, 상호 의존성에 영 향을 미치는 요인에 대해 분석하였다. 공동마케 팅 제휴는 산업에 따라 각기 다른 특성을 가지 고 있기 때문에, 본 연구에서는 국내에서 공동 마케팅 제휴가 가장 활발하게 일어나고 있는 분야 중 이동통신사 제휴를 선정하여 연구를 진행하였다.

우리나라의 이동통신 서비스는 1984년 5월 한 국이동통신에서 차량용 이동전화 서비스를 시 작하면서 제공되기 시작하였다. 국내 이동통신 산업은 1996년 세계 최초로 $\mathrm{CDMA}$ 를 상용한 이래, 음성서비스 시장 및 각종 컨텐츠 시장으 로 꾸준한 성장을 기록하고 있다(이제홍 2010). 1990 년대 후반에는 PCS를 포함하여 다섯 개의 이동통신사가 존재하였으나, 현재는 이동통신시 장의 $50 \%$ 가 넘는 시장점유율을 가진 $\operatorname{SKT}(50.5 \%)$, 2 위 사업자 $\mathrm{KT}(31.5 \%)$ 와 3 위 사업자 LGT $(18 \%)$ 만 남아있다. 2010년 우리나라의 이동통 신 가입자는 약 4,960만 명인데, 이는 인구 1 명 당 1 대 수준의 번호를 확보하고 있다는 뜻이며,
신규가입자 확보가 어려워지자 부가서비스의 강화, 전략단말기 확보, 골드번호 제공 등과 같 은 활동을 통해 타사의 가입자를 전환시키거나 기존고객유지를 강화하는 전략을 추구하고 있 다. 이러한 상황에서 소비자들이 이동전화의 서 비스 품질 중 통신품질과 부가서비스 요인(eg. 멤버십프로그램), 단말기에 대한 만족도, 회사 이미지 등이 이동통신업체를 선택하는 중요한 원인으로 부각되고 있다(김희수 2000; 김문구 외 2005).

이동통신 3 사의 멤버십 서비스는 대부분이 할 인서비스로, 회원등급에 따라 주어진 기간 동안 일정한 포인트 소진한도를 제공하고 그 할인한 도 내에서 멤버십 서비스 제휴파트너에서 특별 우대할인을 받는 구조로 되어있다. KT는 통합 마일리지 멤버십인 olleh KT클럽과 구 KT멤버 십을 운영하고 있으며, SKT의 경우, 회원등급 에 따라 차등적인 할인한도를 부여하는 $\mathrm{T}$ 멤버 십과 $\mathrm{OK}$ 캐쉬백의 고적립과 할인을 받을 수 있 는 T멤버십캐쉬백이라는 두 가지 멤버십 프로 그램, LGT는 LG유플러스 멤버십을 운영하고 있다.

연구의 표본은 국내 $\mathrm{A}$ 이동통신사와 이 통신 사와 제휴관계를 맺고 있는 제휴파트너들로 삼 았고, 거래관련 데이터는 2009년 9월 1일부터 2010년 8월 31일까지의 실제 거래데이터와 A 통신사 및 제휴파트너사의 제휴담당 직원의 설 문을 통해 확보하였다. 본 이동통신사는 기업차 원에서 매년 전체 멤버십 서비스 제휴사에 대 한 설문조사를 진행하고 있으며, 연구관련 설문 은 전체 제휴사에 대한 설문조사 시 함께 조사 하였다. $\mathrm{A}$ 통신사의 경우 제휴카테고리 별로 복 수 이상의 제휴담당 직원이 존재하고 있으며, 
일부는 직접관리를 또 일부는 마케팅대행사를 통해 제휴사를 관리하고 있어, 응답역시 직접수 거 또는 제휴대행사를 통한 설문수거가 이루어 졌다. 이 기간 동안 $\mathrm{A}$ 이동통신사와 제휴관계를 맺은 적이 있는 211 개의 제휴파트너 중, 이벤트 성 행사를 진행하고 제휴를 해지한 제휴파트너 를 제외하고 181 개 제휴파트너의 데이터를 분 석에 사용하였다.

\section{4 변수의 조작적 정의}

본 연구의 가설에서 사용된 변수들 중, 종속 변수인 갈등은 설문을 통하여 조사하였고, 이를 제외한 모든 변수는 기업 간의 실거래자료를 활용하였다. 먼저, 종속변수인 갈등은 설문지로 조사하였으며, 의존성의 선행요인(거래기간, 거 래빈도, 거래특유자산, 거래선의 수)과 의존성 및 상호의존성은 실제 데이터를 통해 분석하였 다. 거래관계 상대방에 대한 설문응답은 특히 서로에게 의존성이 강하거나 힘의 차이가 있을 때에는 응답의 결과가 상대방에 대한 불편한 관계를 만들 수 있을 것이라는 우려나, 연구결 과가 실질적으로 아무런 해결책을 제시해주지 못 하기 때문에 불성실한 응답을 할 수 있기 때문에, 실제 데이터는 이러한 응답오류를 줄여준다. 또 한 설문지만을 통하여 자료를 수집하여 분석을 했을 경우에 발생할 수 있는 동일방법오류를 방지하는 데에도 효과가 크다(Podsakoff et al. 2003).

구체적으로, 상호의존성의 선행요인들인 거래 기간, 거래빈도, 거래특유자산, 거래선의 수는 모두 기업의 실 거래자료 들로 정의하였다. 거 래기간은 공동마케팅 제휴를 실시한 계약시작
일부터 계약해지 일까지의 기간으로 정의하였 다. 본 연구에서는 1년 동안(2009년 9월부터 2010년 8월) A 이동통신사의 멤버십 서비스를 시행한 일자부터, 서비스가 종료된 경우에는 계약 해지 일까지를 거래기간으로 측정하였다. 둘째 로, 거래빈도는 1년 동안(2009년 9월부터 2010 년 8월) $\mathrm{A}$ 이동통신사의 멤버십 서비스의 제 휴파트너(가맹점)에서 고객이 제휴서비스를 이 용한 건수(즉 거래기간 내에 해당 이동통신사 고객의 거래건수)로 정의하였으며, 취소거래가 발생한 경우에는 전체승인 건수에서 취소매출 을 차감한 실제 매출건수를 변수로 측정하였다. 거래특유자산은 제휴파트너로부터 해당기간동 안 고객에게 범용성을 지니는 포인트 적립을 하기위해 지출한 금액의 총합으로 정의하였다. 제휴파트너 입장에서 제휴거래처를 바꾸게 되 면 기존에 자사의 매장을 방문한 고객이 적립 한 마일리지를 더 이상 사용할 수 없게 된다는 점에서 마일리지를 거래특유자산으로 볼 수 있 으며(Chiou \& Droge 2006), 이동통신사 입장에 서는 마일리지를 많이 쌓는 제휴파트너 즉, 고 객들이 자주 방문하고 선호하는 제휴사에서 마 일리지 적립이 늘어나는데 이러한 제휴사가 멤 버십 제휴를 해지하는 경우 통신사 고객들이 타 통신사로 이탈할 가능성이 증가하고 고객만 족도가 줄어들 위험이 있어 마일리지 적립액은 통신사 입장에서도 거래특유자산으로 볼 수 있 다. 넷째로, 거래선의 수는 양사간의 제휴관계 를 제외한 다른 기업과 맺고 있는 제휴관계의 수로, 이동통신사(제휴사 $\mathrm{A}$ )의 거래선의 수는 제휴파트너 $\mathrm{B}$ 와 같은 산업군내의 다른 기업들 과 제휴를 맺고 있는 관계의 수로 정의하였으 며, 제휴파트너 $\mathrm{B}$ 의 거래선의 수는 이동통신사 
(제휴사 A) 이외의 다른 제휴를 맺고 있는 관 계의 수로 정의하였다.

의존성은 이동통신사 $(\mathrm{A})$ 의 입장에서의 의존 성과 제휴파트너 $(\mathrm{B})$ 의 입장에서의 의존성으로 나누어 볼 수있다. 제휴파트너사의 이동통신사 에 대한 의존성은 제휴파트너사의 전체 매출 중 해당 이동통신사 멤버십 서비스에 의해 발 생하는 매출의 비율 $(\%)$ 로 정의하였고, 이동통 신사의 해당 제휴파트너사에 대한 의존성은 해 당기간동안 이동통신사에서 멤버십 서비스를 유 지하기 위해 지출한 전체비용(정산비용 및 마 케팅비용 포함)에서 해당 제휴파트너에 지급한 비용 $(\%)$ 으로 정의하였다.

상호의존성의 총합(total interdependence)은 기 존연구에서와 같이 거래관계에서 당사들의 상대 방에 대한 의존성의 합으로 측정하였다(Gundlach and Cadotte 1994; Kumar et al. 1995). 상호의 존성의 불균형(asymmetry of interdependence) 은 개별제휴사와 이동통신사의 의존성의 차이 로 기존연구에서와 동일하게 상호의존성의 불 균형을 각 기업들의 의존성의 차이에 절대값을 씨워 측정하였다(Kumar et al. 1995).

마지막으로, 갈등은 둘 이상의 관계에서 한 구성원이 다른 구성원의 목표를 달성하는데 방 해가 된다고 인식하는 심리적 대립감과 대립적 행동이 내포된 동태적 행동을 의미한다(Yi et al. 2010). 본 연구에서는 Rosenberg와 Stern (1971) 의 연구에서 사용한 '갈등'의 측정 문항을 신용 카드 제휴상황에 맞게 수정한 Yi et al. (2010) 의 연구를 기반으로 이동통신 산업에 맞게 수 정하여, (1) 이동통신 멤버십 제휴계약 이후 공 동마케팅 제휴운영 및 이행에 있어 사소한 문 제의 발생정도, (2) 제휴계약서에 명시되지 않
은 사항에 대한 요구 (ex. 상품 및 서비스 협찬 요구 또는 각종 수수료 부과), (3) 무리한 마케팅 활동 요구 (ex. 무리한 제품/서비스 할인요구), (4) 이동 통신사의 마케팅비용전가(ex. POP물 제작비용 전가) 등의 4 가지 항목을 5 점 리커트 척도를 사용하여 질문하였으며 제휴관계에 있 는 두 기업의 측정치의 합을 사용하였다.

\section{N. 연구결과}

본 연구에서는 수집된 자료를 SPSS.18.0을 이용하여 기초통계분석을 실시하였고, 설문을 통해 측정된 항목인 갈등에 대해서는 신뢰성 및 타당성 검토를 실시하였다. 또한 심리적인 개념변수와 실제자료를 모두 가지고 있는 연구 모델을 구성하여, PLS방법을 통해서 가설을 검 증하였다. 모델의 추정은 smartPLS2.0 (Ringle et al., 2007)을 활용하였다. PLS는 측정변수의 분포에 대한 가정이 없고, 모수추정방법이 최 소자승법이기 때문에 표준오차가 계산되지 않 으므로 모수추정값의 통계적 검정은 붓스트랩 (bootstrapping) 방법을 통하여 행하였다(Fornell and Bookstein, 1982). 붓스트랩방법은 잭나이 프(Jack Knife)방법과 같이 표본의 수가 한정 되어 있거나 모델의 변수가 모수분포를 가정하 고 있지 않은 경우에 통계값들의 검정을 위해 활용되는 기법으로서(Efron, 1979), 본 연구에 서는 표본재표집 붓스트랩 방법을 통하여 모 수를 반복추정하며 추정된 모수의 분포를 활 용하여 모수추정 값의 통계검정을 시행하였다 (Ringle et al., 2007). 


\section{1 기초통계분석}

총 181 개의 표본을 대상으로 실제 데이터인 거래기간, 거래빈도, 마케팅투자비용, 거래선의 수에 대해 기초통계분석을 〈표 2〉와 같이 실시 하였다. 또한〈표 3〉에 나타난 바와 같이 상관 관계분석의 결과를 살펴보면, 변수들간의 상관 관계는 대부분 유의하며 특히 거래빈도와 마케 팅 투자비용은 매우 높은 양의 상관관계를 갖 는 것을 나타냈다. 또한 상호의존성의 불균형은 거래빈도를 제외한 다른 변수들과 음의 상관관 계가 나타났다.

하지만 실제 데이터는 극단 값(extreme value) 이 존재하기 때문에, 거래기간과 거래빈도는 로
그 치환을 하였고 단위에서도 차이가 크게 나 는 거래특유자산, 거래선의 수, 각 당사자의 의 존성, 상호의존성의 총합, 상호의존성의 불균형 은 표준화 작업 후 로그로 치환하여 분석을 실 시하였다.

\section{2 신뢰성 및 타당성 검토}

본 모델에서는 반영적 측정변수(reflective measurement)들을 가지고 있는 개념변수는 갈 등밖에 없으며, 다른 개념변수들은 모두 한 개 의 측정변수만을 가지고 있다. 따라서 신뢰도나 내적타당성을 통해서 동일한 개념을 측정하고 있는 지 검토할 필요성은 갈등개념 측정변수들

〈표 2〉기초통계분석

\begin{tabular}{c|r|r|r|r|r|r}
\hline 구분 & 표본수 & 최소값 & 최대값 & 평균 & 표준편차 & 분산 \\
\hline 거래기간 & 181 & 3.045 & 8.264 & 6.61778 & .932702 & .870 \\
\hline 거래빈도 & 181 & 0 & 18.337 & 7.30901 & 4.137420 & 17.118 \\
\hline 거래특유자산 & 181 & 0 & 20.917 & 5.57355 & 7.484775 & 56.022 \\
\hline 거래선의수(A) & 181 & 0 & 3.912 & 3.45921 & .630345 & .397 \\
\hline 거래선의수(B) & 181 & 0 & 2.708 & .63971 & .849559 & .722 \\
\hline
\end{tabular}

〈표 3〉 상관관계분석

\begin{tabular}{|c|c|c|c|c|c|c|c|}
\hline & 거래기간 & 거래빈도 & $\begin{array}{c}\text { 거래특유 } \\
\text { 자산 }\end{array}$ & $\begin{array}{c}\text { 거래선의 } \\
\text { 수 }(\mathrm{A})\end{array}$ & $\begin{array}{c}\text { 거래선의 } \\
\text { 수(B) }\end{array}$ & 의존성 $(\mathrm{A})$ & 의존성(B) \\
\hline 거래기간 & 1 & & & & & & \\
\hline 거래빈도 & $.535^{* *}$ & 1 & & & & & \\
\hline 거래특유자산 & $-.250 * *$ & -.085 & 1 & & & & \\
\hline 거래선의수(A) & .082 & .141 & -.047 & 1 & & & \\
\hline 거래선의수(B) & $.589 * *$ & $.582^{*}$ & -.045 & $.185^{*}$ & 1 & & \\
\hline 의존성(A) & $.449 * *$ & $.666^{* *}$ & $.282^{* * *}$ & .086 & $.555^{* *}$ & 1 & \\
\hline 의존성(B) & $.374 * *$ & $.726 * *$ & .066 & .117 & $.362^{* *}$ & $.461^{* *}$ & 1 \\
\hline
\end{tabular}


밖에 없다. 갈등개념의 신뢰도와 AVE(average variance extracted)나 $\mathrm{CR}$ (composite reliability) 은 〈표 4〉과 같이 만족스러운 값을 보여주고 있으며, 〈표 5〉에서 알 수 있는바와 같이 측정 변수들의 추정치들도 통계적으로 유의하게 나 타났다.

\section{$4.3 \mathrm{PLS}$ 구조방정식 모형분석}

내부모델의 결과인〈표 6〉을 보면, 먼저, PLS 분석에서 전체 적합도라고 할 수 있는 종속개 념변수인 갈등의 $R^{2}$ 는 0.50 이 나왔다. 심리변수 들을 활용한 모델들의 값보다는 낮다고 판단할 수 있지만, 실제자료를 활용한 모델임을 감안한 다면 만족스러운 수준이라고 할 수 있다(Fornell and Boostein 1985; 김영찬 - 차재성 2003). 차 이나 총합의 $R^{2}$ 가 1 인 이유는 두 개의 변수는
제휴파트너의 의존성과 이동통신사의 의존성을 단순히 더하거나 뺀 절대 값 이기 때문이다. PLS 가 아닌 MLE방식의 구조방정식모델에서는 이러 한 변수들간의 선형의존성(linear dependency) 때문에 모델추정자체가 안된다. 제휴사의 의존 성과 이동통신사의 의존성은 각각의 원인 독립 변수들로부터의 $\mathrm{R}^{2}$ 가 0.55 와 0.6 으로 나왔다.

구체적으로 가설검증을 위하여 역시 〈표 6〉 및 〈그림 2〉의 추정계수들을 검토해보면, 각각의 의존성에 영향을 미치는 거래관련 변수들 중에 서 우선 이동통신사의 제휴파트너에 대한 의존 성에는 거래기간, 거래빈도, 거래특유자산 등이 유의한 영향을 미치는 것으로 나타났다(H1a, $\mathrm{H} 1 \mathrm{~b}, \mathrm{H1c}$ 지지됨). 그러나 이동통신사의 거래 선의 수는 이동통신사의 제휴파트너에 대한 의 존성에 유의한 영향을 주지 못하는 것(Hld 기 각됨; 유의수준 0.1 에서는 채택됨)으로 나타났

〈표 4〉갈등개념의 신뢰도검증

\begin{tabular}{c|c|c|c|c}
\hline & AVE & $\begin{array}{c}\text { Composite } \\
\text { Reliability }\end{array}$ & $\begin{array}{c}\text { Cronbachs } \\
\text { Alpha }\end{array}$ & Communality \\
\hline 갈등 & 0.63 & 0.93 & 0.92 & 0.63 \\
\hline
\end{tabular}

〈표 5〉 측정변수 추정치(outer model)

\begin{tabular}{c|c|c|c}
\hline & 추정치 & 표준오차 & T-value \\
\hline 갈등_이통사 $1 \leftarrow$ 갈등 & $0.77^{* *}$ & 0.04 & 20.93 \\
\hline 갈등_이통사2 $<$ 갈등 & $0.76^{* *}$ & 0.04 & 19.02 \\
\hline 갈등_이통사 $3 \leftarrow$ 갈등 & $0.75^{* *}$ & 0.05 & 15.17 \\
\hline 갈등_이통사4 4 갈등 & $0.72^{* *}$ & 0.05 & 15.44 \\
\hline 갈등_제휴사1 1 갈등 & $0.80^{* *}$ & 0.03 & 25.39 \\
\hline 갈등_제휴사2 2 갈등 & $0.81^{* *}$ & 0.03 & 26.22 \\
\hline 갈등_제휴사3 $\leftarrow$ 갈등 & $0.87^{* *}$ & 0.02 & 44.95 \\
\hline 갈등_제휴사4 4 갈등 & $0.85^{* *}$ & 0.02 & 37.02 \\
\hline
\end{tabular}


〈표 6〉개념변수관계 추정치(inner model)

\begin{tabular}{|c|c|c|c|c|}
\hline & 추정치 & 표준오차 & T-value & R-Square \\
\hline 상호의존성 불균형 $\rightarrow$ 갈등 & -0.06 & 0.06 & 0.97 & 0.50 \\
\hline 상호의존성 총합 $\rightarrow$ 갈등 & $0.67^{* *}$ & 0.04 & 15.42 & \\
\hline 이통통신사 의존성 $\rightarrow$ 상호의존성 불균형 & $-1.12^{* *}$ & 0.03 & 36.79 & 1.00 \\
\hline 제휴사의 의존성 $\rightarrow$ 상호의존성 불균형 & $0.55^{* *}$ & 0.06 & 9.10 & \\
\hline 이동통신사 의존성 $\rightarrow$ 상호의존성 총합 & $0.77^{* *}$ & 0.02 & 33.08 & 1.00 \\
\hline 제휴사의 의존성 $\rightarrow$ 상호의존성 총합 & $0.37^{* *}$ & 0.03 & 11.32 & \\
\hline 거래기간 $\rightarrow$ 제휴사의 의존성 & 0.07 & 0.08 & 0.84 & 0.55 \\
\hline 거래빈도 $\rightarrow$ 제휴사의 의존성 & $0.77^{* *}$ & 0.05 & 16.71 & \\
\hline 제휴사의 거래선의 수 $\rightarrow$ 제휴사의 의존성 & -0.12 & 0.07 & 1.87 & \\
\hline 거래특유자산 $\rightarrow$ 제휴사의 의존성 & $0.14^{* *}$ & 0.05 & 2.87 & \\
\hline 거래기간 $\rightarrow$ 이동통신사의 의존성 & $0.24^{* *}$ & 0.08 & 3.08 & 0.60 \\
\hline 거래빈도 $\rightarrow$ 이동통신사의 의존성 & $0.57^{* *}$ & 0.07 & 8.15 & \\
\hline 이통통신사 거래선의 수 $\rightarrow$ 이동통신사의 의존성 & 0.00 & 0.07 & 0.07 & \\
\hline 거래특유자산 $\rightarrow$ 이통통신사의 의존성 & $0.39 * *$ & 0.05 & 7.34 & \\
\hline
\end{tabular}

$*: p<0.05, * *: p<0.01$

〈그림 2〉 연구결과

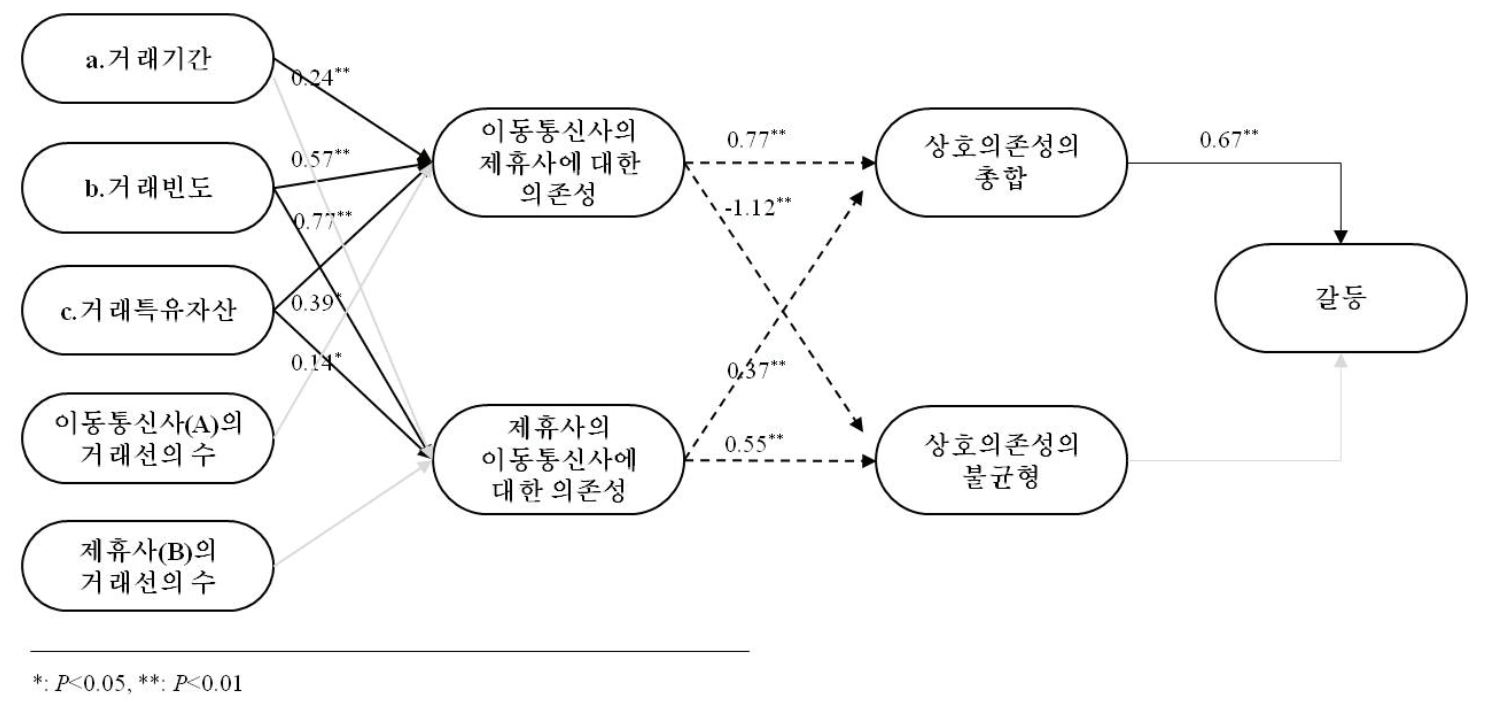

다. 이는 제휴관계에 있어서 이동통신사 $(\mathrm{A})$ 가 제휴사 $(\mathrm{B})$ 에 비해 상대적으로 우월적 지위를 차 지하고 있기 때문에, 해당 제휴카테고리에 있어
신규제휴사가 추가되거나, 감소된다고 하더라 도, 단순한 제휴파트너의 증감이 이동통신사의 의존성에 영향을 주지 못하는 것으로 추측된다. 
둘째로, 제휴파트너의 이동통신사에 대한 의 존성에 영향을 미치는 거래관련 변수들을 살펴 보면, 거래빈도, 거래특유자산은 제휴사의 의존
성에 유의미한 영향을 미치고 있으나 $(\mathrm{H} 2 \mathrm{~b}, \mathrm{H} 2 \mathrm{c}$ 지지됨), 거래기간 및 제휴파트너의 거래선의 수 는 $(+)$ 방향성은 있으나 통계적으로 유의한 영

〈표 7〉 원인변수들의 전체효과

\begin{tabular}{|c|c|c|c|}
\hline & 추정치 & 표준오차 & T-value \\
\hline 거래기간 $\rightarrow$ 갈등 & $0.15^{* *}$ & 0.05 & 3.37 \\
\hline 거래기간 $\rightarrow$ 이동통신사의 의존성 & $0.24^{* *}$ & 0.08 & 3.08 \\
\hline 거래기간 $\rightarrow$ 제휴사의 의존성 & 0.07 & 0.08 & 0.84 \\
\hline 거래기간 $\rightarrow$ 상호의존성 불균형 & $-0.23 *$ & 0.11 & 2.20 \\
\hline 거래기간 $\rightarrow$ 상호의존성 총합 & $0.21 * *$ & 0.06 & 3.43 \\
\hline 거래빈도 $\rightarrow$ 갈등 & $0.50 * *$ & 0.06 & 8.99 \\
\hline 거래빈도 $\rightarrow$ 이동통신사의 의존성 & $0.57^{* * *}$ & 0.07 & 8.15 \\
\hline 거래빈도 $\rightarrow$ 제휴사의 의존성 & $0.77^{* * *}$ & 0.05 & 16.71 \\
\hline 거래빈도 $\rightarrow$ 상호의존성 불균형 & $-0.22^{*}$ & 0.10 & 2.25 \\
\hline 거래빈도 $\rightarrow$ 상호의존성 총합 & $0.73^{* *}$ & 0.06 & 12.69 \\
\hline 이통통신사 거래선의 수 $\rightarrow$ 갈등 & 0.00 & 0.04 & 0.07 \\
\hline 이동통신사 거래선의 수 $\rightarrow$ 이동통신사의 의존성 & 0.00 & 0.07 & 0.07 \\
\hline 이동통신사 거래선의 수 $\rightarrow$ 상호의존성의 불균형 & -0.01 & 0.07 & 0.07 \\
\hline 이동통신사 거래선의 수 $\rightarrow$ 상호의존성 총합 & 0.00 & 0.05 & 0.07 \\
\hline 제휴사 거래선의 수 $\rightarrow$ 갈등 & -0.03 & 0.01 & 1.77 \\
\hline 제휴사 거래선의 수 $\rightarrow$ 제휴사의 의존성 & -0.12 & 0.07 & 1.87 \\
\hline 제휴사 거래선의 수 $\rightarrow$ 상호의존성 불균형 & -0.07 & 0.04 & 1.78 \\
\hline 제휴사 거래선의 수 $\rightarrow$ 상호의존성 총합 & -0.05 & 0.03 & 1.81 \\
\hline 이동통신사의 의존성 $\rightarrow$ 갈등 & $0.58 * *$ & 0.05 & 11.30 \\
\hline 이동통신사의 의존성 $\rightarrow$ 상호의존성의 불균형 & $-1.12^{* *}$ & 0.03 & 36.79 \\
\hline 이동통신사의 의존성 $\rightarrow$ 상호의존성 총합 & $0.77^{* *}$ & 0.02 & 33.08 \\
\hline 제휴사의 의존성 $\rightarrow$ 갈등 & $0.22 * *$ & 0.04 & 5.05 \\
\hline 제휴사의 의존성 $\rightarrow$ 상호의존성의 불균형 & $0.55^{* *}$ & 0.06 & 9.10 \\
\hline 제휴사의 의존성 $\rightarrow$ 상호의존성 총합 & $0.37 * *$ & 0.03 & 11.32 \\
\hline 상호의존성 불균형 $\rightarrow$ 갈등 & -0.06 & 0.06 & 0.97 \\
\hline 상호의존성 총합 $\rightarrow$ 갈등 & $0.67^{* * *}$ & 0.04 & 15.42 \\
\hline 거래특유자산 $\rightarrow$ 갈등 & $0.26^{* * *}$ & 0.03 & 7.38 \\
\hline 거래특유자산 $\rightarrow$ 이동통신사 의존성 & $0.39 * *$ & 0.05 & 7.34 \\
\hline 거래특유자산 $\rightarrow$ 제휴사의 의존성 & $0.14^{* *}$ & 0.05 & 2.87 \\
\hline 거래특유자산 $\rightarrow$ 상호의존성 불균형 & $-0.36^{* *}$ & 0.06 & 5.58 \\
\hline 거래특유자산 $\rightarrow$ 상호의존성 총합 & $0.35^{* *}$ & 0.05 & 7.53 \\
\hline
\end{tabular}

*: $p<0.05{ }^{* *}: p<0.01$

94 한국마케팅저널 제13권 제3호 2011년 10월 
향을 주지 못하는 것으로 나타났다( $\mathrm{H} 2 \mathrm{a}, \mathrm{H} 2 \mathrm{~d}$ 기각됨). 따라서 이동통신사와 제휴사의 공동마 케팅에서 실질적인 제휴기간이나 대체가능한 제휴관계의 수가 중요한 것이 아니라, 거래액이 나 빈도 그리고 투자금액과 같은 금전적이고 정량적인 요소가 훨씬 더 중요한 역할을 한다 고 말할 수 있다.

셋째로 상호의존성의 총합이 증가하면 갈등역 시 증가하는 것으로 나타나, 이동통신사와 제휴 사의 공동마케팅 제휴관계에 있어서는 예상대 로 쌍무적 억제이론보다 갈등나선형 이론의 설 명력이 높아 보인다(H3 지지됨).

넷째로 상호의존성의 불균형은 갈등에 통계적 으로 유의미한 영향을 미치지 못하는 것으로 나타났으나(H4 기각됨), 추정계수의 부호 방향 성으로 볼 때, 가설과 같이 쌍무적 억제이론보 다 갈등나선형 이론이론이 현재의 자료와 연구 모델에서 보면, 더 맞는 이론이라고 할 수 있겠다. 이동통신사와 제휴사의 의존성이 상호의존성 의 불균형과 상호의존성의 총합에 미치는 계수 는 상호의존성의 정의에 따라서 산술적으로 계 산된 수치이기 때문에 별도의 해석이 필요하지 는 않다.

본 모델의 종속변수인 갈등의 변량중 약 $50 \%$ 는 본 모델의 원인변수들이 의존성을 매개변수 로 하여서 결정하는 것으로 나타났다. 〈표 7〉은 각 원인변수들이 갈등이나 매개변수들에 미치 는 전체효과를 보여주고 있다. 이동통신사의 제 휴사에 대한 의존성 $(0.58)$ 과 거래빈도 $(0.50)$ 가 갈등을 유발하는 가장 큰 원인으로 나타났다.

\section{V. 결 론}

\section{1 연구의 결과}

본 연구는 이동통신사와 제휴파트너 간의 멤 버십서비스 제휴에 있어서 쌍방의존성에 영향 을 미치는 거래관련 변수들이 상호의존성에 미 치는 영향 및 상호의존성이 갈등에 미치는 영 향의 정도를 실증자료를 통하여 관련이론을 검 증하고자 하였다. 특히 쌍무적 억제이론과 갈등 나선형 이론 중 어떤 이론이 더 맞는지를 거래 당사자 양쪽으로 부터 설문지를 통한 측정변수 이외에 실제 거래 자료를 통한 변수를 활용하 여 연구를 수행하였다. 이를 통해 제휴관계를 맺고 있는 기업들의 갈등수준을 완화시키거나 이러한 기업들이 지속적인 관계구축을 하는데 있어 실무적인 시사점을 제공하였다.

구조방정식 연구모델분석을 통한 결과는 구체 적으로 다음과 같이 해석할 수 있다. 첫째, 이 동통신사의 멤버십 제휴서비스 환경에서는 상 호의존성의 총합이 증가할수록 갈등은 증가하 고, 상호의존성의 불균형이 증가할수록 갈등은 감소하는 것을 알 수 있었다. 물론, 상호의존성 의 불균형과 갈등수준의 관계는 통계적으로 유 의미한 결과를 얻지는 못했으나, 두 변수간의 관계가 (-)관계임은 파악할 수 있었고 이는 갈 등 나선형이론을 지지하는 결과임을 알 수 있다.

둘째, 거래관련 변수들과 각 제휴파트너 별 의 존성과의 관계를 확인해 볼 때, 거래기간, 거래빈 도, 거래특유자산은 이동통신사 관점에서 제휴파 트너에 대한 의존성에 유의미한 영향을 끼치며, 거래빈도, 거래특유자산, 제휴사의 거래선의 수는 
제휴파트너 관점에서 이동통신사에 대한 의존성 에 영향을 끼치고 있음을 알 수 있었다. 또한 전 체효과를 분석해볼 때 거래기간, 거래빈도, 거래 특유자산은 갈등수준에 직접적인 영향을 미치는 것으로 나타나, 고객의 이용빈도가 높고 특유자 산에 대한 투자가 많은 제휴파트너(e.g. 마일리 지 적립이 높은 제휴사)에 대한 관리는 전반적인 제휴프로그램의 성과나 지속적인 관계유지 관점 에서 중요한 역할을 할 것으로 판단된다. 본 산 업의 특성을 감안해 볼 때, 현실적으로 당장 이 득이 될 수 있는 거래빈도나 거래특유자산이 중 요한 요소들로 생각이 되고, 통신사와 제휴파트 너 사이의 힘의 차이가 존재하고, 비교적 안정적 인 구조를 유지하고 있기 때문에, 대체 거래선의 수는 의존성에 크게 영향을 미치지 않는 것으로 보인다. 또한 이동통신사 입장에서 자사의 고객 니즈에 맞는 서비스를 제공하는 제휴파트너와는 지속적이고 장기적인 거래관계를 유지하려고 노 력할 것이므로, 결국 거래기간은 제휴파트너에 대한 의존성과 관련이 있는 것으로 판단된다.

셋째, 이동통신사의 의존성은 제휴파트너의 의존성에 비해 프로그램의 갈등수준에 더 유의 미한 영향을 미치고 있음을 알 수 있었다. 이는 다시 말하자면, 이동통신사 관점에서 전체 로열 티 프로그램 지출 비용에서 차지하는 비율이 높은 제휴파트너가, 제휴파트너 전체매출에서 통신사 멤버십 고객이 차지하는 비율이 높은 제휴사에 비해 제휴갈등 수준이 높다는 것을 의미하며, 이동통신사는 고객의 사용빈도를 제 한하거나 제휴사의 거래특유자산에 대한 투자 를 증가시키는 등의 전략을 통해 효과적인 갈 등관리를 할 수 있을 것이다.

넷째, 이동통신사의 로열티프로그램에 참여하
고 있는 제휴파트너는 이동통신사와의 관계에 서 효율적인 갈등관리를 위해 자사의 전체 매 출에서 이동통신사 멤버십 고객이 차지하는 비 율을 관리할 필요가 있으며, 해당 통신사 이외 의 신용카드사 또는 다른 기업들과의 제휴를 통해 거래선을 증가시킴으로써 통신사에 대한 의존도를 조절할 필요가 있다.

\section{2 연구의 의의 및 한계점}

본 연구는 실제 거래 데이터를 이용하여 상호 의존성과 갈등간의 관계를 최초로 규명한 연구구 이고, 제휴 관계에서 한쪽만을 측정하는 기존의 연구들과는 달리 제휴관계를 구성하는 양쪽의 측 정변수를 통해 분석한 연구임에도 불구하고 다음 과 같은 한계점을 지니고 있다. 첫째로 갈등의 선 행요인으로 상호의존성(상호의존성의 총합, 상호 의존성 불균형) 이외의 다른 변수들을 제시하지 못했으며, 또한 제휴관계에 있는 두 기업의 각각 의 의존성에 영향을 주는 요인으로 거래관련변수 (거래기간, 거래빈도, 거래특유자산, 거래선의 수) 이외의 다른 요인에 대해 제시하지 못했다. 물론 실제 거래데이터를 사용하였기 때문에 계량화된 변수들을 사용하게 되었으나, 향후 연구에서는 다 양한 변수들을 사용하여 외적타당성을 더 높일 수 있는 결과를 제시해야 할 필요가 있다.

둘째로, 갈등 측정에 있어, 잠재적인 갈등을 포 함하지 않은 실제로 드러난 갈등만을 측정하여 분석에 사용하였으며, 상호갈등이라는 제휴관계 에 있는 두 기업의 갈등수준을 측정하는데 있어 각 기업의 마케팅담당자로부터 얻은 응답결과의 합을 측정치로 사용하였다. 그러나, 실제로 제휴 관계에 있는 두 파트너사가 느끼는 갈등수준은 
매우 다를 수 있음에도 불구하고, 현재의 측정방 식으로 한쪽은 갈등수준이 매우 낮다고 평가하고 있으나, 상대방은 매우 높다고 느끼고 있는 경우 와 양쪽 다 보통이라고 생각하는 경우를 유사한 수준의 갈등상황으로 평가하게 된다. 아울러, 갈 등정도를 측정함에 있어 제휴관계에 있는 이동통 신사에서 조사하였다는 점이 응답자의 설문결과 에 영향을 미칠 수 있다는 점 역시 한계점으로 제기될 수 있다. 따라서 향후연구에서는 양자관 계(dyadic relationship)에서의 갈등을 측정하는 방식을 좀 더 정교화 할 필요가 있겠다.

셋째로, 본 연구의 이론적 근거로 쌍무적 억 제이론과 갈등나선형 이론을 제시하였는데, 이 러한 이론에서는 상호의존성과 갈등수준을 매 개하는 변수들로 보복에 대한 두려움과 공격에 대한 예상 또는 힘의 행사에 대한 유혹과 같은 변수들을 제시하고 있다. 그러나 본 연구에서는 상호의존성과 갈등의 직접관계만 규명하였을 뿐 매개 역할을 할 수 있는 변수들에 대해는 자료를 수집하여 그 관계를 명확히 규명하지 못했다. 따라서 향후 연구에서는 상호의존성과 갈등사이의 매개 또는 조절 역할을 할 수 있는 변수들에 대해 살펴볼 필요가 있겠다.

마지막으로, 본 연구는 이동통신사의 공동마 케팅 제휴현황에 대한 연구로 외식이나 엔터테 인먼트(ex.영화, 놀이동산 등) 등의 산업 영역 으로 제휴파트너가 치우쳐 있다는 점에서 이동 통신사의 공동마케팅 상황이 아닌 다른 산업의 환경으로 일반화 하는데 한계가 있을 수 있겠다.

〈논문 접수일: 2011. 06. 20〉

〈1차 수정일: 2011. 07. 22〉

〈2차 수정일: 2011. 08, 20〉

〈게재 확정일: 2011. 08. 22〉

\section{참고문헌}

김 영, 배일현 (2006), “공동마케팅에서 전략적 제휴성과의 핵심선행요인에 관한 연구, 상 품학연구, 24(2), 37-66.

김영찬 · 차재성 (2003), "고객만족도 측정방법 론과 전략적 활용," 마케팅연구, 18(1), 113132.

김문구, 박명철, 전동헌, 박종현 (2003), “이동통

신 서비스에 전환장벽이 고객유지에 미치는 조절효과에 관한 실증적 연구, 경영정보학 연구, 13(3), 107-130.

김재욱, 최지호, 김종근 (2004), “상호의존성과 갈등 간 관계에 있어서 신뢰의 조절효과," 유통연구, 9(4), 43-63.

김종근, 김재욱 (2005), “불균형적 상호의존성과 갈등 간 비선형적 관계에 대한 연구, 유통 연구, 10(2), 49-72.

김희수 (2000), "국내 이동전화시장의 가입전환

및 고객충성도 결정요인 분석," 정보사회연

구, 2000(1), 1-18.

신영식, 차경천 (2011), “제휴카드 할인프로그램 이 외식업의 수익성에 미치는 영향, 한국 마케팅저널, 12(4), 55-78.

이석규, 김경식(2005), “고객 보상프로그램의 효 과성에 관한연구: 신규 고객 유치를 위한 전략적 프레임웍," 한국마케팅저널, 7(2), 123-139

이제홍 (2010), "이동통신 3사의 통신서비스 품 질에 관한 연구, " $\mathrm{e}^{-}$비즈니스연구, 11(1), 507-527.

한상린 (2003), “산업재 시장에서 구매자-공급 
자 관계의 선행변수와 거래성과에 관한 연 구," 유통연구, 8(1), 1-18.

Anderson, J. C. and J. A. Narus (1990), “A Model of the Distributor's Perspective of Distributor-Manufacturer Working Relationships," Journal of Marketing, 48(4), 62-74. Bacharach, S. B. and E. J. Lawler (1981), Bargaining: Power, Tactics, and Outcomes, San Francisco: Jossey-Bass.

Brown, J. R., Lusch, R. F. and Muehling D. D. (1983), "Conflict and Power-Dependence Relations in Retailer-Supplier Channels," Journal of Retailing, 59(4), 53-80.

Buchanan, Lauranne. (1992), "Vertical Trade Relationship: The Role of Dependence and Symmetry in Attaining Organizational Goals," Journal of Marketing Research, 29(1), 65-75

Bucklin, Louis P. and Sanjit Sengupta (1993), "Organizing Successful Co-Marketing Alliance," Journal of Marketing, 57(April), $32-46$.

Chiou, J. and Droge C. (2006), "Service Quality, Trust, Specific Asset Investment, and Expertise: Direct and Indirect Effect in a Satisfaction-Loyalty Framework," Journal of the Academy of Marketing Science, $34(4)$, 613-627

Coleman, P.T. (2000), "Power and conflict," in M. Deutch \& P.T. Coleman (Eds.), The Handbook of conflict resolution: Theory and Practice, San Francisco: Jossey-Bass Deutsch, M. and R. M. Krauss (1962), "Studies of Interpersonal Bargaining," Journal of Conflict Resolution, 6(1), 52-76.

Efron, B. (1979), "Bootstrap methods: Another look at the Jackknife," The Annals of Statistics, 7(1), 1-26.

Emerson, R. M. (1962), “Power-Dependence Relations," American Sociological Review, 27(February), 31-41.

Frazier, Gary L. (1999), "Organizing and Managing Channels of Distributions," Journal of the Academy of Marketing Science, 27(2), 226-240.

Frazier, Gary L., James D. Gill, and Sudhir H. Kale (1989), "Dealer Dependence Levels and Reciprocal Actions in a Channel of Distribution in a Developing Country," Journal of Marketing, 53(1), 50-69.

Frazier, Gary L., Raymond C. Rody (1991), "The Use of Influence Strategies in Interfirm Relationships in Industrial Product Channels," Journal of Marketing, 55(January), 52-69

Fornell, C., and F. L. Bookstein (1982), "Two structural equation models: LISREL and PLS applied to consumer exit-voice theory," Journal of Marketing Research, 19(4), 440-452.

Fornell, C., and Y. Yi (1992), “Assumption of the two-step approach to latent variable modeling," Sociological Methods and Research, 20(3), 291-320.

Gates, Stephen (1993), Strategic Alliance: Guideline for Successful Management, New York, 
The Conference Board Inc.

Gundlach, G. T. and E. R. Cadotte (1994),

"Exchange Interdependence and Interfirm

Interaction: Research in a Simulated Chan-

nel Setting," Journal of Marketing Research, 31(4), 516-532.

Heide, Jan B. (1994), "Interorganizational Governance in Marketing Channels," Journal of Marketing, 58(1), 71-85.

Heide, Jan B. and John, George. (1988), "The Role of Dependence Balancing in Safeguarding Transaction-Specific Assets in Conventional Channels," Journal of Marketing, 52(1), 20-35.

Heide, Jan B. and John, George (1990), "Alliances in Industrial Purchasing: The Determinants of Joint Action in Buyer-Supplier Relationships," Journal of Marketing Research, 27(Frbruary), 24-36.

Kale, Prashant., Singh,Harbir, and Perlmutter, Howard (2000), "Learning and Protection of Proprietary Assets in Strategic Alliances: Building Relational Capital, Strategic Management Journal, 21(3), 217-237.

Kalwani, Manohar U, and Narakesari Narayandas (1995), “Long-Term Manufacturer-Supplier Relationships: Do They Pay Off for Supplier Firms?," Journal of Marketing, 59(1), 1-16.

Kandemir, D., A. Taprak, and S. T. Cavusgil (2006), "Alliance Orientation: Conceptualizatioin, Measurement, and Impact on Market Performance," Journal of The Aca- demy of Marketing Science, 34(3), 324340.

Kumar, N., L. K. Scheer, and J-B. E. M. Steenkamp (1995), "The Effects of Perceived Interdependence on Dealer Attitudes," Journal of Marketing Research, 32(3), 348-35.

Lawler, E. J. (1986), "Bilateral Deterrence and Conflict Spiral: A Theoretical Analysis," in E. J. Lawler, ed. Advances in Group Processes, 3, Greenwich, CT: JAI, 107-130.

Lawler, E, J. and Bacharach, S. B. (1987), "Comparison of dependence and punitive forms of power," Social Forces, 66(2), 446-462.

Lawler, E. J., R. S. Ford, and M. A. Blegen (1988), "Coercive Capability in Conflict: A Test of Bilateral Deterrence Versus Conflict Spiral Theory," Social Psychology Quarterly, 51(2), 93-107.

Lorange, P. and J. Roos (1992), Strategic Alliances, Cambridge: Blackwell.

McCann, Joseph E. and Ferry, Diane L. (1979), "An Approach for Assessing and Managing Inter-Unit Interdependence," The Academy of Management, 4(1), 113-119.

McCarthy, Patrick. (2010), “Applying Conflict Theory to Strategy Selection in Scholarly Communication," UC San Diego Libraries, UC San Diego. [http://escholarship.ucop. edu/uc/item/8gw0k3x3]

Mitchell, Will, and Singh, Kulwant. (1996),

"Survival of Businesses Using Collaborative 
Relationships to Commercialize Complex Goods," Strategic Management Journal, 17 (3), 169-195.

Park. C. Whan, Sung Youl Jun and Allan D. Shocker (1996), "Composite Brand Alliance: An Investigation of Extension and Feedback Effect," Journal of Marketing Research, 33(4), 453-466.

Parkhe, Arvind (1993), "Strategic Alliance Structuring: A Game Theoretic and Transaction Cost Examination of Interfirm $\mathrm{Co}^{-}$ operation," Academy of Management Journal, 36(4), 794-829

Pfeffer, J. and G. R. Salancik (1978), The External Control of Organizations, New York: Haper \& Row Publisher, Inc.

Phillips, Lynn W. (1981), “Assessing Measurement Error in Key Information Reports: A Methodological Note on Organizational Analysis in Marketing," Journal of Marketing Research, 18(4), 395-415

Podsakoff, P.M., S.B. MacKenzie, J.Y. Lee, and N.P. Podsakoff (2003), "Common method biases in behavioral research: a critical review of the literature and recommended remedies," Journal of Applied Psychology, 88(5), 879-903

Porter, Michael. E., and Mark. B. Fuller (1986), Coalitions and Global Strategy, Harvard Business School Press.

Pruitt, Dean G., and Rubin, Jeffery Z. (1986), Social Conflict: Escalation, Stalemate, and Settlement. New York: Random House.
Rathneshwar, S., and A. D. Shocker (1991), "Substitution in Use and the Role of Usage Context in Product Category Structures," Journal of Marketing Research, 28(3), 281-295.

Rich, Michael K. (2003), "Requirements for Successful Marketing Alliances," Journal of Business \& Industrial Marketing, 18(4), 447-456

Ringle, Christian, Sven Wende, and Alexander Will (2007), smartPLS 2.0.M3[http://www. smartpls.de]

Rosenberg, Larry J., and Stern, Louis W. (1971), "Conflict Measurement in the Distribution Channel," Journal of Marketing Research, 8(4), 437-442.

Spekman, Robert E., Isabella Lynn A. and MacAvoy, Thomas (2000), Alliance Competence, Maximizing the Value of Your Partnerships, John Wiley \& Sons: New York.

Venkatesh, R., and V. Mahajan (1997), "Products with Branded Components: An Approach for Premium Pricing and Partner Selection," Marketing Science, 16(2), 146165.

Yi, Ho Taek, Lee, Joseph and Dubinsky, Alan J. (2010), “An Empirical Investigation of Relational Conflicts in Co-Marketing Alliances," Journal of Business to Business Marketing, 17(3), 249-278. 


\title{
An Empirical Investigation of Relationship Between Interdependence and Conflict in Co-marketing Alliance
}

\author{
Yi, Ho Taek* \\ Cho, Young Wook** \\ Kim, Ju Young***
}

\begin{abstract}
Researchers in channel dyads have devoted much attention to relationship between interdependence (i.e. interdependence enymmetry and total interdependence) and conflict that promote channel performance. In social science, in spite of the inconsistent results in marketing practice, there are two contradictory theories explain the relationship between interdependence and conflict - bilateral deterrence theory and conflict spiral theory.

The authors apply these theories to co-marketing alliance situation in terms that this relationship is also incorporated both company's dependence, either from one company's perspective or each partner about its respective dependence. Using survey data and archival data from 181 companies enlisted in a telecommunication membership program, the authors find out the relationship between interdependence and conflict as well as investigate the antecedents of interdependence - transaction age, transaction frequency, the numbers of alliance partner, and co-marketing alliance specific assets according to previous researches.

Using PLS analysis, the authors demonstrate that, with increasing total interdependence in a telecommunication membership program, two co-marketing partners' conflict level is increased in accord with the author's conflict spiral theory predictions. As expected, higher interdependence asymmetry has negative value to level of conflict even though this result is not statistically significant.

Other findings can be summarized as follows. In the perspective of telecommunication company, transaction age, transaction frequency, and co-marketing alliance specific assets have influence on its dependence on a partner as independent variables. To the contrary, in a partner's perspective, transaction frequency, co-marketing alliance specific assets and the numbers of alliance partner have significantly impact on its dependence on a telecommunication company. In direct effect analysis, it is shown that
\end{abstract}

\footnotetext{
* Ph. D. Candidate, Sogang Business School(hotaekyi@sogang.ac.kr), 1st author

** MBA, Sogang Business School(ywcho@sogang.ac.kr), corresponding author

*** Professor, Sogang Business School(jkimsg@sogang.ac.kr)
} 
transaction age, frequency and co-marketing alliance specific assets have direct influence on conflict. This results suggest that it is more useful for a telecommunication company to select a co-marketing partner which is frequently used by customers and earned high rates of mileage.

In addition, the results show that dependence of a telecommunication company on a co-marketing partner is more significantly effected to co-marketing alliance conflict than partner's one. It provide an effective conflict management strategy to a telecommunication company for controling customer's usage rate or having the co-marketing partner deposit high level of alliance specific investment (i.e. mileage). To a co-marketing partner of telecommunication company, it is required control the percentage of co-marketing sales in total sales revenue or seek various co-marketing partners in order for co-marketing conflict management. The research implications, limitation and future research of these results are discussed.

Key words: Conflict, Conflict spiral theory, Co-marketing alliance, Independence (Independence asymmetry, Total independence), Bilateral deterrence theory, Telecommunication industry 